\title{
CORNEAL ENDOTHELIAL CELL CHANGES AFTER TRABECULECTOMY WITH MITOMYCIN-C IN GLAUCOMA PATIENTS
}

\author{
By
Mohamed Abd El-Aziz Mohamed Salah, Hassan El-Sayed El-Baz and Sayed Mostafa El-Sayed \\ Department of Ophthalmology, Faculty of Medicine, Al Azhar University, Cairo, Egypt \\ E-mail: zezoo1219@gmail.com
}

\begin{abstract}
Background: Mitomycin $\mathrm{C}$ is an antimetabolite and affects corneal endothelial cells as measured by noncontact specular microscopy after trabeculectomy with mitomycin-C (MMC).

Objective: To evaluate the corneal endothelial cells changes after trabeculectomy with MMC.

Patients and methods: Patients were categorized into 2 groups, group $\mathrm{A}(25$ eyes) were managed by trabeculectomy with mitomycin-C injection, group B (25 eyes) were managed by trabeculectomy with mitomycin-C sponge-applied technique which was carried out on patients attending at Ophthalmology Department of Al-Azhar University Hospitals from March 2019 to February 2021. Follow-up by specular microscopy preoperatively and 1 month and 6 months postoperatively to evaluate corneal endothelial cells density and morphological changes.
\end{abstract}

Results: There was a significant reduction in the endothelial cell density and percentage of hexagonal cells and increased variation in cell size in the two studied groups after 1 month and 6 months compared with preoperative values. With no differences between the two studied groups.

Conclusion: Trabeculectomy with both MMC injection and sponge applied caused a significant loss of the corneal endothelial cells intraoperatively or at the early postoperative period. Progressive cell losses due to MMC were not a major concern.

Keywords: Changes; Corneal; Endothelial; Mitomycin-C; Trabeculectomy.

\section{INTRODUCTION}

Trabeculectomy is the most commonly used glaucoma surgical procedure for lowering intra ocular pressure by providing an artificial drainage pathway from the anterior chamber to the subconjunctival space. However, the success rate of this surgery has been limited by postoperative fibroblast proliferation and scarring of the filtering bleb (Singh and Singh, 2013).
Antifibroblastic agents, such as mitomycin-C (MMC), are commonly used adjunctively to prevent scar formation and improve the success rate of trabeculectomy. The antifibroblastic activity of MMC has proven to be beneficial to modulate the wound healing after pterygium excision, refractive surgery and to reduce cicatrisation after trabeculectomy as primary surgery and in cases of complicated glaucoma (Hau, 2011). 
MMC is derived from Streptomyces caespitosus with alkylating properties that inhibits DNA synthesis. It is suggested that, in high doses MMC has a cytotoxic effect that is independent of cell cycle (Hollo, 2012).

In trabeculectomy, MMC may penetrate into adjacent ocular tissues beyond its application site. Since corneal endothelial cells lack division capacity, possible insults are irreversible and cell density diminishes gradually (Juan et al., 2013).

Experiments have confirmed direct toxicity of MMC to endothelial cells but some authors believe that with the concentrations and methods used in trabeculectomy, MMC is unlikely to cause endothelial damage (Joyce, 2013).

Corneal endothelium is a nonregenerating predominantly hexagonal cell which covers the posterior surface of descemet's membrane. Endothelium is metabolically active and plays an important role in maintaining the corneal transparency by pumping water from stroma to the aqueous humor and keeping the stroma in the dehydrated level of $70 \%$ of water (Srinivas, 2011).

Corneal endothelial cell density and morphology can be analyzed using specular microscope. The specular microscope has been shown to be reliable and reproducible. Non-contact Specular microscope provides a non-invasive method of morphological analysis of the corneal endothelial cell layer. It makes the measurement of endothelial cell density (ECD), measurement of coefficient of variation $(\mathrm{CV})$ in the cell size as well as hexagonal appearance of the cell. These parameters provide an index of the functional status of corneal endothelial layer (Sihota et al., 2019).

The aim of the present study was to highlighten the corneal endothelial cells changes after subscleral Trab with MMC.

\section{PATIENTS AND METHODS}

A prospective interventional comparative clinical trial study was carried out on 50 eyes of 30 patients attending the Ophthalmology Department of Al-Azhar University Hospitals (Cairo, Egypt). The study included two equal groups. They were prepared for subscleral trab with MMC from March 2019 to February 2021. Follow-up for those patients was done by specular microscopy preoperatively, 1 month and 6 months postoperatively to evaluate the corneal endothelial changes.

All study procedures were carried out and approved by the Ethical Committee of Al-Azhar Faculty of Medicine. Written informed consent was obtained from each patient before enrollment in the study.

Inclusion criteria of selected cases was uncontrolled glaucoma despite maximal tolerated medical therapy, primary open or closed angle glaucoma, and poor compliance with medications. Patients were excluded from the study if they had secondary glaucoma, congenital glaucoma, traumatic glaucoma, corneal abnormality, developing cataract simultaneously or during the follow-up period.

\section{Surgical procedure:}

Group A: The MMC injection technique was used. Our MMC preparation included mixing $4 \mathrm{mg}$ of MMC powder with $10 \mathrm{ml}$ sterile water diluent to achieve $0.4 \mathrm{mg} / \mathrm{ml}$ 
concentration. For MMC injection, we used a $20-\mu \mathrm{g}$ preparation starting with MMC $0.4 \mathrm{mg} / \mathrm{mL}$, diluting $0.1 \mathrm{~mL}$ of MMC $(40 \mu \mathrm{g})$ in $0.1 \mathrm{~mL}$ of lidocaine (1:1, total volume of $0.2 \mathrm{~mL}$ ). Half of that solution $(0.1 \mathrm{~mL}$ of MMC: lidocaine [20 $\mu \mathrm{g}]$ ) was used for injection. then instillation of topical anesthesia. A 28gauge needle was introduced 7 to $8 \mathrm{~mm}$ from the limbus. The MMC preparation was injected subconjunctivally posterior to the anticipated flap location. The conjunctival peritomy was completed. Then wet-field bipolar cautery was performed for hemostasis with copious irrigation using saline solution. A 15 no blade was then used to dissect the partial thickness $4 \times 4 \mathrm{~mm}$ scleral flap. A paracentesis was performed using a $1-\mathrm{mm}$ side port blade in the temporal cornea. A sclerotomy was created. A peripheral iridectomy was created .The scleral flap was repositioned in place using two 10-0 nylon sutures. Once flow was determined to be adequate, with the anterior chamber remaining well-maintained, conjunctival closure proceeded using a running 8-0 vicryl suture. At the end of the case, the conjunctival incision was checked for lack of leakage.

Group B: The sponge-applied technique was used. On separate surgical sponges MMC solution of $0.2 \mathrm{mg} / \mathrm{mL}$ was used and then inserted subconjunctivally at the surgical site. The sponges were applied for $2 \mathrm{~min}$ and removed, and then the area was copiously irrigated with saline solution

Postoperatively, all patients were treated with antibiotics eye drops (gatifloxacin administered four times per day) and corticosteroids eye drops (prednisolone acetate administered four times per day for 2 weeks that were tapered off slowly over 6-8 weeks) Antiglaucoma eye drops were added if necessary based on the IOP.

Postoperatively, all patients were examined at the first postoperative month and 6 months by slit lamp and by measuring the IOP. Specular microscopy was performed at 1 month and 6 months postoperatively to evaluate the cell density and CV using TOPCON SP-1P specular microscope (Topcon SP-1P; Topcon Inc., Tokyo, Japan).Topcon SP-1P is an automatic noncontact specular microscope, which automatically evaluates, calculates, and displays the cell density and CV. Cell density is a measurement of cell density in $\mathrm{mm} 2$ (cells/mm2), which varies in normal population from 2000 to 3200 cells $/ \mathrm{mm} 2$. The coefficient of variation in the endothelial cells size (CV) normally is less than 40. polymegathism means increase in $\mathrm{CV}$. The percentage of hexagonal cells (Hexagonality) normally more than 60. Pleomorphism is significant change of the regular hexagonal pattern of the endothelium (Figure 1). 


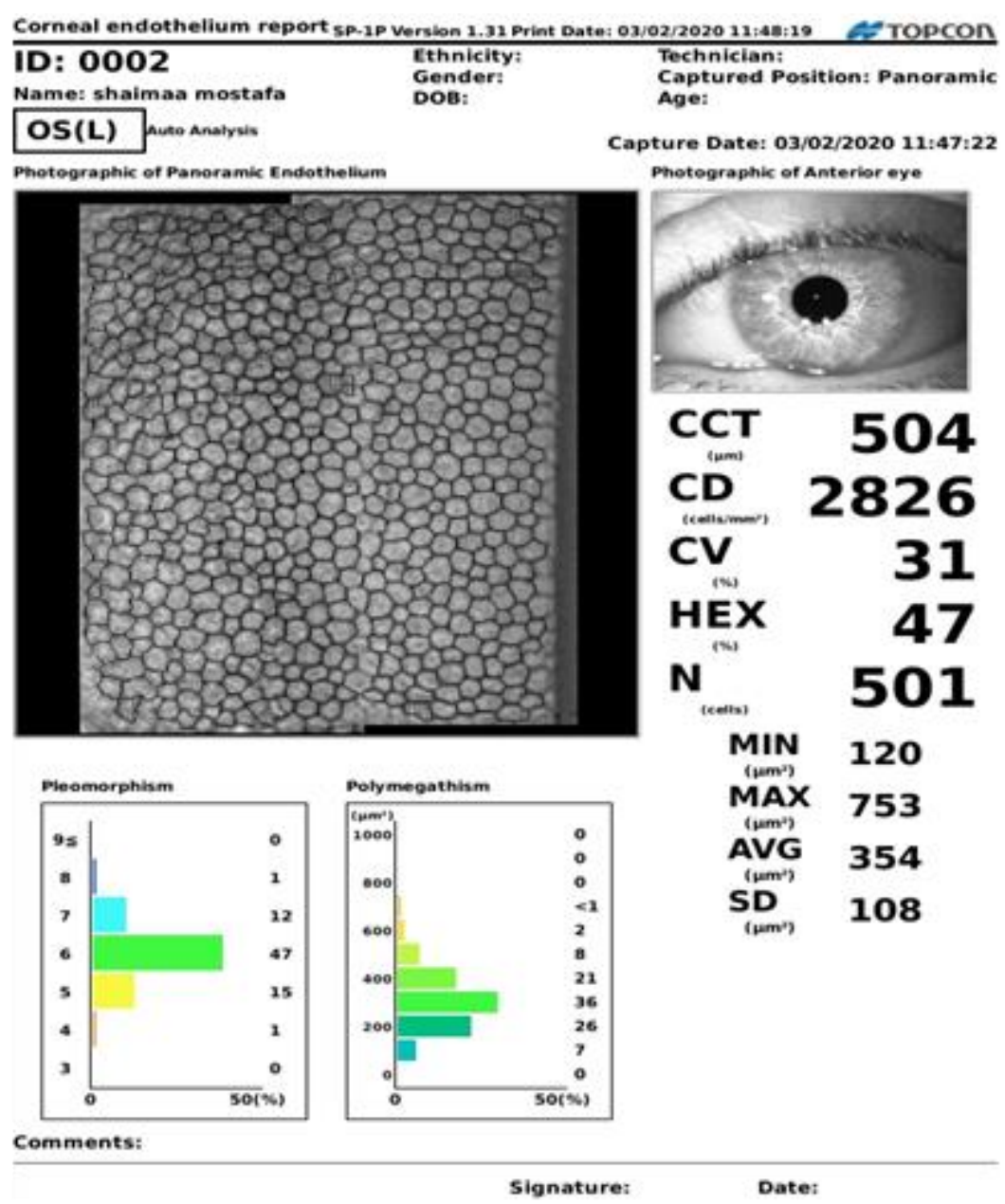

Figure (1): Printout of Topcon SP-1p specular microscopy.

\section{Statistical analysis:}

Data were collected, revised, coded and entered to the Statistical Package for Social Science (IBM SPSS) version 23. The quantitative data were presented as mean, standard deviations and ranges when their distribution found parametric and qualitative data were presented as number and percentages.

The comparison between two paired groups with quantitative data and parametric distribution was done by using Paired t-test.
The comparison between two independent groups with quantitative data and parametric distribution was done by using Independent t-test.

The confidence interval was set to $95 \%$ and the margin of error accepted was set to $5 \%$. So, the p-value $<0.05$ was considered significant. 


\section{RESULTS}

Group A (MMC injection) included 25 eyes of 15 patients (6 males and 9 females) while group B (MMC sponge) included 25 eyes of 15 patients ( 7 males and 8 females) the mean age of group $\mathrm{A}$ was $52.71 \pm 7.87$ while in group $B$ the mean age of group A was $53.57 \pm 11.4$. in terms of age and gender ,there was There was no statistically significant difference between the two groups.

This study included 45 eyes of primary open angle glaucoma representing $90 \%$ of cases, 5 eyes of pseudoexfoliation glaucoma representing $10 \%$ of cases.

Specular microscopy preoperatively, one month and six months postoperatively : Mean central corneal thickness (CCT) in group $\mathrm{A}$ was $512.10 \pm 33.52 \mu \mathrm{m}$ before surgery which increased to $518.40 \pm 5.92$ $\mu \mathrm{m}$ at 1 month and $518.60 \pm 32.13 \mu \mathrm{m}$ at 6 months after surgery with no further increase. These differences were significant $\quad(\mathrm{P}=0.027$ and 0.029 respectively) between the preoperative and $1 \mathrm{~m}$ after and $6 \mathrm{~m}$ after. Also in group B In, the mean CCT was $514.90 \pm 43.59 \mu \mathrm{m}$ before surgery which increased to $518.40 \pm 5.92 \mu \mathrm{m}$ at 1 month and $519.80 \pm 6.53 \mu \mathrm{m}$ at 6 months after surgery with no further increase. These differences were significant $(\mathrm{P}=0.042$ and 0.045 respectively) between the preoperative and $1 \mathrm{~m}$ after and $6 \mathrm{~m}$ after with no statistically difference between the two study groups (Table 1).

\section{Table (1): Preoperative and postoperative mean central corneal thickness}

\begin{tabular}{|c|c|c|c|}
\hline $\begin{array}{l}\text { Central } \\
\text { corneal } \\
\text { thickness }\end{array}$ & $\begin{array}{c}\text { Group A: } \\
\text { Trabeculectomy with } \\
\text { adjuvant MMC } \\
\text { injection }(n=25)\end{array}$ & $\begin{array}{c}\text { Group B: } \\
\text { Trabeculectomy with } \\
\text { adjuvant MMC } \\
\text { sponge }(n=25)\end{array}$ & $\begin{array}{c}\text { p- } \\
\text { value }\end{array}$ \\
\hline \multicolumn{4}{|l|}{ Preoperative } \\
\hline Mean \pm SD & $512.10 \pm 33.52$ & $514.90 \pm 43.59$ & \multirow{2}{*}{0.800} \\
\hline Range & $448-559$ & $440-570$ & \\
\hline \multicolumn{4}{|l|}{ After 1month } \\
\hline Mean \pm SD & $518.40 \pm 5.92$ & $519.80 \pm 6.53$ & \multirow{2}{*}{0.431} \\
\hline Range & $460-582$ & $444-566$ & \\
\hline \multicolumn{4}{|l|}{ After 6month } \\
\hline Mean \pm SD & $518.60 \pm 32.13$ & $519.95 \pm 39.18$ & \multirow{2}{*}{0.946} \\
\hline Range & $460-560$ & $445-565$ & \\
\hline \multicolumn{4}{|l|}{ P-value between: } \\
\hline Pre \& Afterlmonth & 0.027 & 0.042 & \\
\hline Pre \& After 6 months & 0.029 & 0.045 & \\
\hline After1m \& After 6 months & 0.89 & 0.89 & \\
\hline
\end{tabular}

Endothelial cell density in group A was $3378.60 \pm 166.55$ before surgery which decreased to $3117.50 \pm 106.99$ at 1 month and $3164.00 \pm 190.62$ at 6 months after surgery with no further decrease. These differences were statistically significant $(\mathrm{P}$ $<0.001$ and $<0.001$ respectively) between the preoperative and 1month after and 6 months after. Also, in group B, the mean ECD was $3304.20 \pm 170.64$ before surgery which decreased to $3113.60 \pm 109.21$ at 1 month and $3100.00 \pm 154.29$ at 6 months after surgery with no further decrease. These differences were statistically significant $\quad(\mathrm{P} \quad<0.001$ and $\quad<0.001$ respectively) between the preoperative and 1 month after and 6 months after with no statistically difference between the two study groups (Table 2) (Figure 2). 
Table (2): Preoperative and postoperative mean endothelial cell density in group A and $B$

\begin{tabular}{|c|c|c|c|}
\hline $\begin{array}{l}\text { Endothelial } \\
\text { cell density }\end{array}$ & $\begin{array}{c}\text { Group A: } \\
\text { Trabeculectomy } \\
\text { with adjuvant MMC } \\
\text { injection }(n=25)\end{array}$ & $\begin{array}{c}\text { Group B: } \\
\text { Trabeculectomy } \\
\text { with adjuvant MMC } \\
\text { sponge }(n=25)\end{array}$ & p-value \\
\hline \multicolumn{4}{|l|}{ Pre } \\
\hline Mean \pm SD & $3378.60 \pm 166.55$ & $3304.20 \pm 170.64$ & \multirow{2}{*}{0.125} \\
\hline Range & $3123-3558$ & $3103-3629$ & \\
\hline \multicolumn{4}{|l|}{ After 1m } \\
\hline Mean \pm SD & $3177.50 \pm 106.99$ & $3113.60 \pm 109.21$ & \multirow{2}{*}{0.042} \\
\hline Range & $2761-3326$ & $3095-3548$ & \\
\hline \multicolumn{4}{|l|}{ After 6m } \\
\hline Mean \pm SD & $3164.00 \pm 190.62$ & $3100.00 \pm 154.29$ & \multirow{2}{*}{0.198} \\
\hline Range & $2700-3380$ & $3090-3550$ & \\
\hline \multicolumn{4}{|l|}{ P-value between: } \\
\hline Pre \& After 1month & $<0.001$ & $<0.001$ & \\
\hline Pre \& After 6 months & $<0.001$ & $<0.001$ & \\
\hline $\begin{array}{l}\text { Afterlmonth \& After } \\
\text { 6months }\end{array}$ & 0.300 & 0.290 & \\
\hline
\end{tabular}

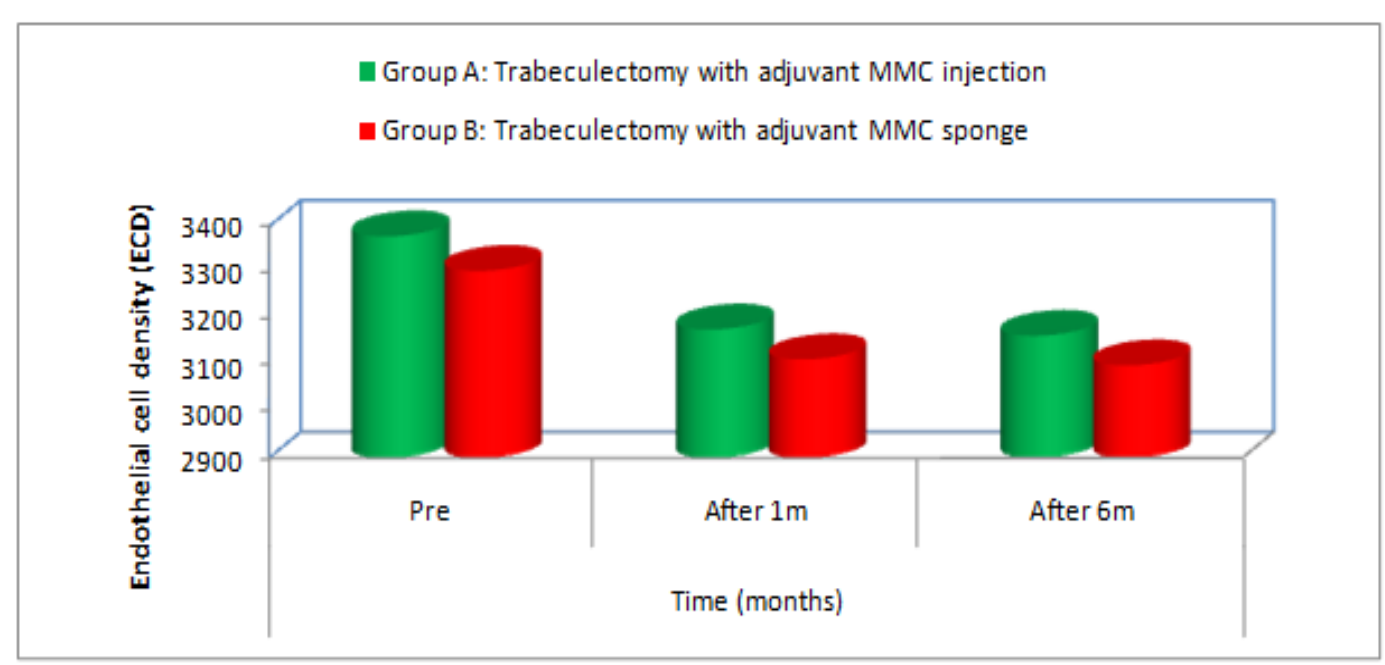

Figure (2): Endothelial cell density in group A and group B

The mean coefficient of variation $(\mathrm{CV})$ in group A was $24.00 \% \pm 2.31$ before surgery which increased to $25.30 \% \pm 2.50$ at 1 month and $26.90 \% \pm 2.80$ at 6 months after surgery with no further increase. These differences were significant $(\mathrm{P}<0.001$ and $<0.001$ respectively) between the preoperative and $1 \mathrm{~m}$ after and $6 \mathrm{~m}$ after also in group $\mathrm{B}$ the mean coefficient of variation (CV) was $24.00 \%$ \pm 2.05 before surgery which increased to $25.80 \% \pm 2.20$ at 1 month and $27.0 \%$ \pm 2.83 at 6 months after surgery with no further increase. These differences were significant $\quad(\mathrm{P}<0.001$ and $<0.001$ respectively) between the preoperative and 1 month after and 6 months after with no statistically difference between the two study groups (Table 3 ). 
Table (3): Preoperative and postoperative mean coefficient of variation in group A and $B$

\begin{tabular}{|c|c|c|c|}
\hline Coefficient & $\begin{array}{c}\text { Group A: } \\
\text { Trabeculectomy with } \\
\text { adjuvant MMC } \\
\text { injection }(n=25)\end{array}$ & $\begin{array}{c}\text { Group B: } \\
\text { Trabeculectomy with } \\
\text { adjuvant MMC } \\
\text { sponge }(n=25)\end{array}$ & p-value \\
\hline \multicolumn{4}{|l|}{ Pre } \\
\hline Mean \pm SD & $24.00 \% \pm 2.31$ & $24.00 \% \pm 2.05$ & \multirow{2}{*}{1.000} \\
\hline Range & $21-29 \%$ & $21-27 \%$ & \\
\hline \multicolumn{4}{|l|}{ After 1 month } \\
\hline Mean \pm SD & $25.30 \% \pm 2.50$ & $25.80 \% \pm 2.20$ & \multirow{2}{*}{0.456} \\
\hline Range & $25-34 \%$ & $23-32 \%$ & \\
\hline \multicolumn{4}{|l|}{ After 6 months } \\
\hline Mean \pm SD & $26.90 \% \pm 2.80$ & $27.0 \% \pm 2.83$ & \multirow{2}{*}{0.9} \\
\hline Range & $25-3 \%$ & $23-34 \%$ & \\
\hline \multicolumn{4}{|l|}{ P-value between: } \\
\hline Pre \& Afterlmonth & $<0.001$ & $<0.001$ & \\
\hline Pre \& After6months & $<0.001$ & $<0.001$ & \\
\hline $\begin{array}{c}\text { After 1month \& After } \\
6 \text { months }\end{array}$ & 0.024 & 0.081 & \\
\hline
\end{tabular}

The mean percentage of hexagonal cells (HEX) in group A was $50.50 \% \pm$ 3.95before surgery which decreased to $47.10 \% \pm 3.78$ at 1 month and $45.00 \% \pm$ 3.65at 6 months after surgery with no further decrease. These differences were statistically significant $(\mathrm{P}<0.001$ and $<0.001$ respectively) between the preoperative and $1 \mathrm{~m}$ after and $6 \mathrm{~m}$ after. Also in group $\mathrm{B}$, the mean ECD was

Table (4): Preoperative and postoperative mean hexagonal cells

\begin{tabular}{|c|c|c|c|}
\hline $\begin{array}{l}\text { Percentage of } \\
\text { hexagonal cells }\end{array}$ & $\begin{array}{c}\text { Group A: } \\
\text { Trabeculectomy with } \\
\text { adjuvant MMC } \\
\text { injection }(n=25)\end{array}$ & $\begin{array}{c}\text { Group B: } \\
\text { Trabeculectomy with } \\
\text { adjuvant MMC } \\
\text { sponge }(n=25)\end{array}$ & p-value \\
\hline \multicolumn{4}{|l|}{ Pre } \\
\hline Mean \pm SD & $50.50 \% \pm 3.95$ & $49.40 \% \pm 4.25$ & \multirow{2}{*}{0.348} \\
\hline Range & $44 \%-56 \%$ & $41 \%-55 \%$ & \\
\hline \multicolumn{4}{|l|}{ After 1month } \\
\hline Mean \pm SD & $47.10 \% \pm 3.78$ & $46.70 \% \pm 3.20$ & \multirow{2}{*}{0.688} \\
\hline Range & $40 \%-51 \%$ & $40 \%-52 \%$ & \\
\hline \multicolumn{4}{|l|}{ After 6months } \\
\hline Mean \pm SD & $45.00 \% \pm 3.65$ & $44.80 \% \pm 2.90$ & \multirow{2}{*}{0.831} \\
\hline Range & $28 \%-45 \%$ & $40 \%-50 \%$ & \\
\hline \multicolumn{4}{|c|}{ P-value between: } \\
\hline Pre \& Afterlm & $<0.001$ & 0.023 & \\
\hline Pre \& After6m & $<0.001$ & 0.011 & \\
\hline Afterlm \& After $6 m$ & 0.083 & 0.063 & \\
\hline
\end{tabular}

$49.40 \% \pm 4.25$ before surgery which decreased to $46.70 \% \pm 3.20$ at 1 month and $44.80 \% \pm 2.90$ at 6 months after surgery with no further decrease. These differences were statistically significant $(\mathrm{P}$ $<0.001$ and $<0.001$ respectively) between the preoperative and $1 \mathrm{~m}$ after and $6 \mathrm{~m}$ after with no statistically difference between the two study groups (Table 4). 


\section{DISCUSSION}

A prospective research was done on 50 eyes, divided into two equal groups: Group A was managed by trabeculectomy with MMC injection, while group B was managed by trabeculectomy with MMC sponges at the Ophthalmology Department of Al-Azhar University Hospitals (Cairo, Egypt) during the period between March 2019 and February 2021. Follow-up for those patients was done by specular microscopy preoperatively 1 month, 3 months and 6 months postoperatively to evaluate the corneal endothelial changes.

Non-contact specular microscope (Topcon sp-1p, Topcon Medical Inc., Japan) was done preoperatively and one month and six months post-operatively to assess the corneal endothelium as regard ECD (cells $\left./ \mathrm{mm}^{2}\right), \mathrm{CV}$ in cell size, HEX and CCT.

This study showed that Trab with MMC was more useful with less need for visits within 6 months and no further intervention. Exposure of large surface area led to more diffuse and elevated blebs.

In this study, the reduction of endothelial cell density in group A was statistically significant ( $\mathrm{P}<0.001$ and $<0.001$ respectively) between the preoperative and 1 month after and 6 months after. Also in group B, Differences were statistically significant $(\mathrm{P}<0.001$ and $<0.001$ respectively) between the preoperative and 1 month after and 6 months after with no statistically difference between the two study groups. This was comparable with María et al. (2021) who reported that after subscleral Trab with adjunctive MMC, there was an endothelial cell loss of $14 \%$ after 3 months and $6.8 \%$ after 1 year.

This was opposite to some experimental studies, which have suggested that MMC-related endothelial cell loss in clinical settings is unlikely to occur. These differences observed in clinical studies may be due to variations in study design, sample size, surgical technique, and follow-up period. Such differences reflect that the MMC effect on CECD is small. Although this little cell loss would probably cause insignificant clinical problem, a low or borderline preoperative endothelial cell density could significantly be affected by the use of MMC intraoperative, leading to decompensated cornea clinically, as observed by some authors.

Our study showed a significant postoperative CECD reduction compared with the preoperative count, but without interference with corneal clarity. So, patient selection is still an important factor, as mentioned before, moderate corneal endothelial loss in these patients may result in its decompensating. In those patients, use of ocular viscoelastic devices may be useful in reducing CECD loss induced by MMC (Demir et al., 2019).

CECD reduction during the first month postoperatively was significantly higher than CECD reduction from the first to 6 month postoperative. This clarified that MMC-induced corneal endothelial toxicity occurred intraoperative or in the early postoperative period up to 1 month, and that progressive endothelial cell loss should not be a major important. This was comparable with Storr et al. (2010) who found that significant cell reduction during or immediately after MMC- 
augmented Trab with no progressive cell loss from 3 to 12 months. Zarei et al. (2018) observed that cell loss of $3.4 \%$ in the control group without the use of MMC in the first month and loss of $7.2 \%$ in the MMC group. However, the endothelium was of the central cornea and did not assess the peripheral cornea. So, significant regional changes in cell density could not be understood. Endothelial cell toxicity may be localized or more prominent at the site of application, and central corneal endothelial assessment may not actually reflect the whole cornea.

Coefficient of variation increased slightly 1 month after surgery. This indicated that active cellular enlargement and realignment were taking place. From 1 to 6 months, $\mathrm{CV}$ continued to increase slightly and did not return to pre-operative values, but this was not statistically significant (Kazuyuki et al., 2021).

\section{CONCLUSION}

Trabeculectomy with MMC caused a significant loss of the endothelial cell density and percentage of hexagonal cells and increased variation in cell size in the two studied groups after 1 month and 6 months compared with preoperative values. With no differences between the two studied groups. Progressive cell losses due to MMC were not a major concern.

\section{REFERENCES}

1. Demir A. G., Olgun A., Guven D., Demir M., Sendul S. Y., Acar O. and Kacar H. (2019): The effect of combined phacotrabeculectomy, trabeculectomy and phacoemulsification on the corneal endothelium in the early stage: a preliminary study. International ophthalmology, 39(9):2121-12.
2. Hau S (2011): Corneal complications of glaucoma surgery. Curr Opinion in Ophthalmol, 20; 131-36.

3. Hollo G (2012): Wound healing and glaucoma surgery: modulating the scarring process with conventional antimetabolites and new molecules. Dev Ophthalmol; 50:7989.

4. Joyce NC (2013): Proliferative capacity of the corneal endothelium. Progress in retinal and eye research, 22(3): 359-89.

5. Juan D, Maybee D and Vania C (2013): Corneal Endothelial Cells Loss after Trabeculectomy For Glaucoma. ARVO Journal, 54:15-18.

6. - Kazuyuki H ,Eri N, Kaori U, Shino S and Yoshiaki K (2021): Effect of trabeculectomy on corneal endothelial cell loss. $\mathrm{Br} \mathrm{J}$ Ophthalmol., 25:62-4.

7. María S, Antonio O, Miriam M, Gabriel A, Paloma S, José R, Jaime $M$ and María V (2021): Corneal endothelial cell loss after trabeculectomy and phacoemulsification in one or two steps: a prospective study. EYE, 15:65-9.

8. Sihota R, Sharma $T$ and Agarwal HC (2019): Intraoperative mitomycin $C$ and the corneal endothelium. Acta Ophthalmol Scand, 76:80-2.

9. Singh $P$ and Singh $A$ (2013): Mitomycin-C use in ophthalmology. J Pharm, 3(1):12-4.

10. Storr T, Norreguard JC, Ahmed S and Paulsen A (2010): Corneal endothelial cell loss after mitomycin C-augmented trabeculectomy. J Glaucoma, 17:654-7.

11. Srinivas SP (2011): Dynamic regulation of barrier integrity of the corneal endothelium. Optometry and vision science: official publication of the American Academy of Optometry, 87(4): 239-45.

12. Zarei R, Zarei M, Fakhraie G, Eslami Y, Moghimi S, Masoud $M$ and Abdollahi A (2018): Effect of Mitomycin-C Augmented Trabeculectomy on Corneal Endothelial Cells. BMC Ophthalmology, 18:243-50. 
التغير ات في الطبقة المبطنة للقرنية بعد عملية قط التر ابطات

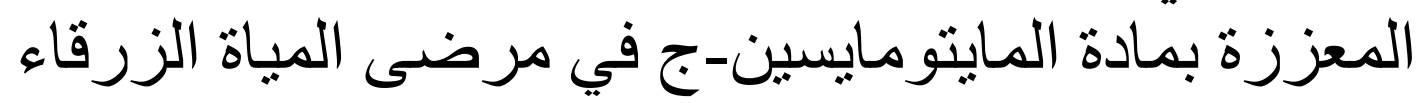
محمد عبد العزيز محمد صلاح، حسن السيد الباز، سيد مصطفى السيد طب وجراحة العين، كلية الطب، جامعة الأزهر

E-mail: zezoo1219@gmail.com

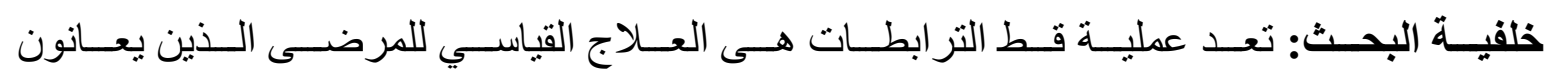
من المباة الزرقاء الأولية مفتوحة الزاوية.

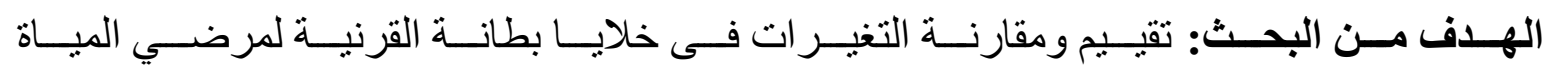

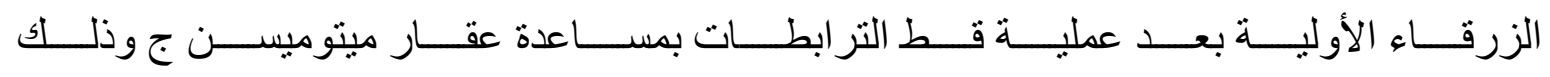

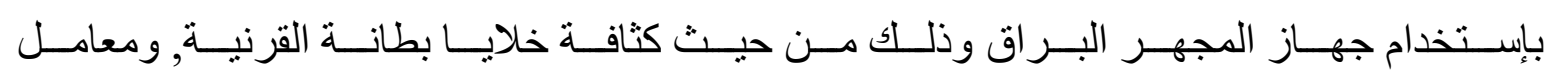

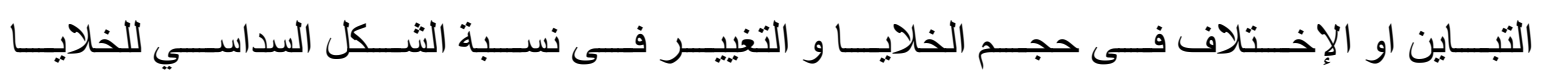

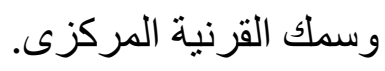

المرضى وطرق البحث: إنتملت الدراسة على مجمو عتين متساويتين:

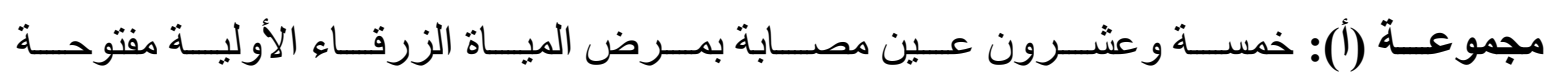

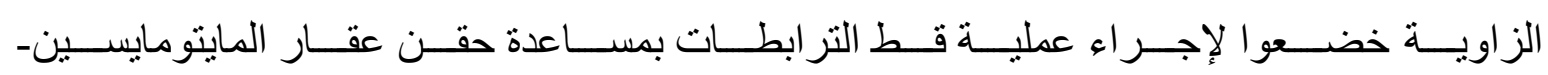

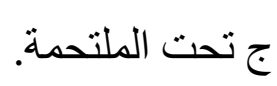

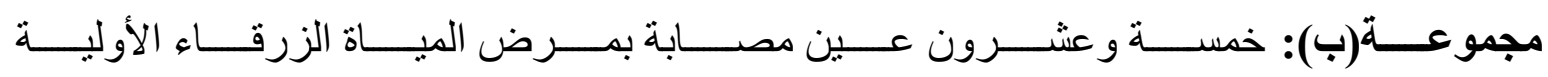

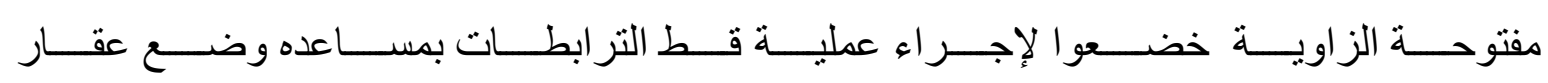
المايتو مايسين-ج بالاسفنج على الصلبة.

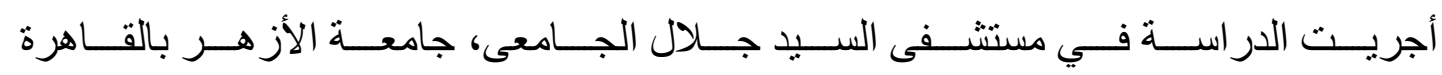

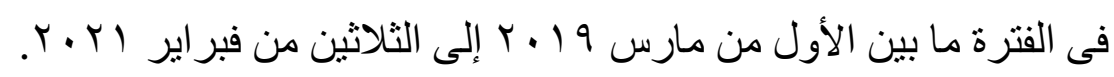

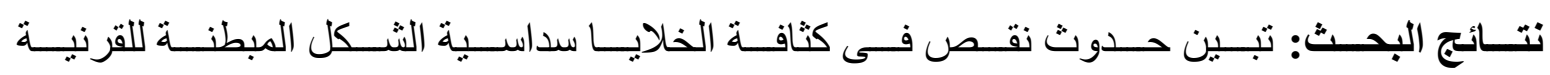

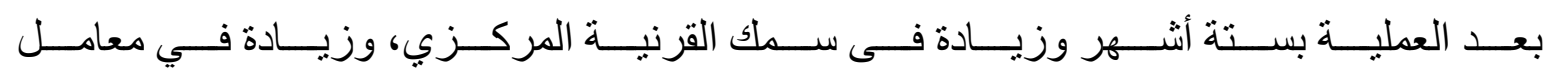

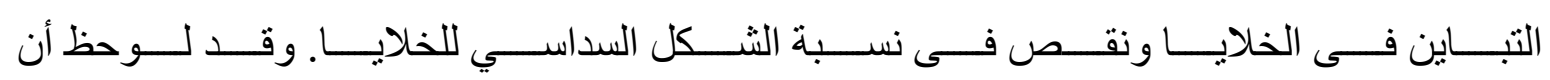




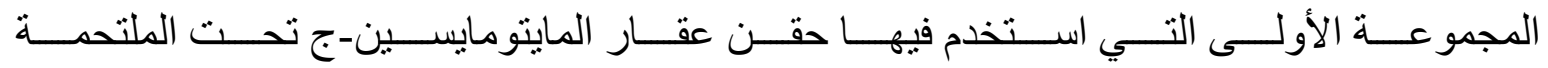

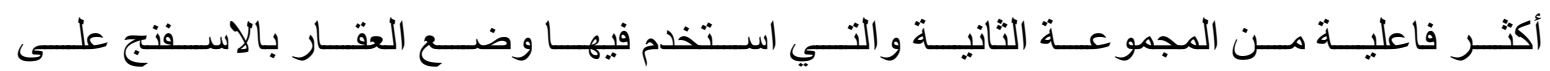

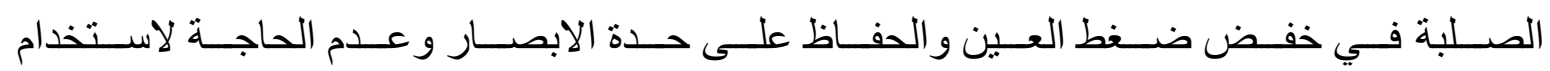

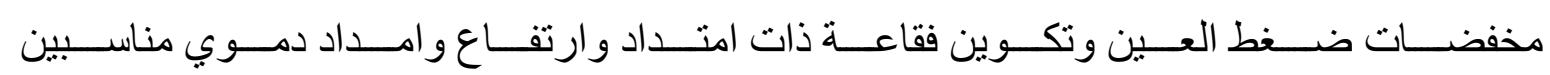

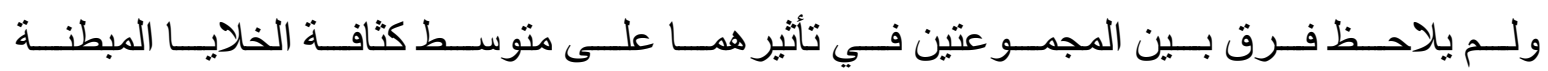
للقرنية ومعامل التباين في الخلايا ونسبة الثكل السداسي للخلايا.

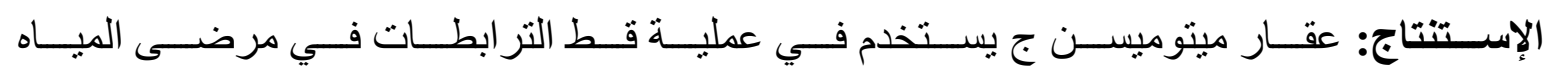

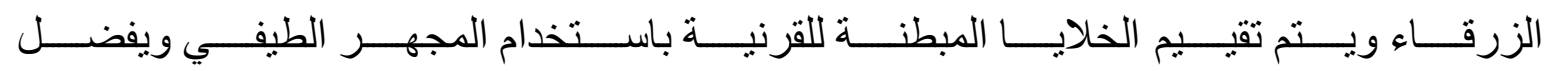
اعطاؤه بطريق الحقن تحت الملتحمة.

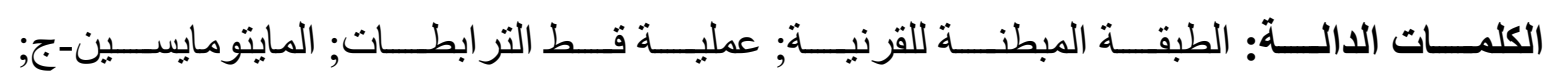
مرضى المياة الزرقاء. 